Finally, commencing in 1987, the Québec National Assembly passed a series of implementation laws to bring into effect a new civil code, to be called the Civil Code of Québec (C.C.Q.). A 1997 Act of the National Assembly set the final stage for the implementation of the new Code.

Most of the provisions of the new Code had come into force by January 1, 1994. The 3,168 articles of the C.C.Q. bear some resemblance to the original Civil Code of Lower Canada but incorporate a significantly different interpretation of private law.

Further information about McGill University and its involvement with the development of the Civil Code of Québec may be obtained by contacting the Law Library at (514) 398-4715, extension 1556.

Information about the Archives of the Civil Code Revision Office may be obtained via the World Wide Web at URL: http://www.library.mcgill.ca/ccro/

\title{
A Frank Scott letter from 1937
}

\author{
By A.J. Hobbins \\ Associate Director, Administration, Libraries
}

John Peters Humphrey (1905-1995), author of the first draft of the Universal Declaration of Human Rights, and F.R. Scott (1899-1985), famed constitutional lawyer and poet, became friends when they met as undergraduates at McGill University in. 1926, and they later spent many years together as colleagues in the McGill Faculty of Law. Humphrey, two years behind Scott in law school and six years younger, was very much influenced by Scott's ideas. Humphrey returned to Montreal in 1930 after studying in France for a year, He observed the misery of the Great Depression first hand and immediately recognized the need for a social safety net. He became a socialist and a member of the League for Social Reconstruction, an organization co-founded by Scott. Humphrey practiced law in Montreal for a few years before McGill's Dean of Law, Percy Corbett (1892-1983), invited him to join the Faculty to teach Corbett's course in Roman law and eventually that in international law. At this time the only other full-time members of the faculty were Scott and (Charles) Stuart Le Mesurier (b. 1888). Humphrey accepted the position, which was held for a year whilst he studied Roman law in Paris on a fellowship from the Carnegie Endowment for World Peace.

The year 1936/37 was a dramatic one on the European stage. In Hitler's Germany the Olympic Games became a propaganda event, while thousands of German citizens - principally alleged communists, Jews and homosexuals - were being placed in concentration camps. Mussolini's Italy was gearing up for the conquest of its African empire. In Spain the civil war, a clash in extreme ideologies, was beginning in earnest. In the Soviet Union Stalin had already begun his great purges, while from abroad the exiled. Trotsky vilified him. Humphrey visited Germany and Italy, and observed developments elsewhere with interest. He reported many of his observations in letters to his sister Ruth, and to his colleagues at McGill. One of Frank Scott's replies $^{1}$ is given below, followed by some contextual explanation for each paragraph. 


\author{
Faculty of Law \\ McGill University \\ Montreal
}

February 14th 1937

Dear John,

I have to thank you and Jeanne for your letter about your Italian experiences, and also for the very interesting book by Gide which Marian and I have enjoyed discussing - if enjoyment is the word to use about a rather discouraging situation. I felt very much as Gide did when I was in Russia, only then the element of repression seemed to be getting better all the time instead of worse. Now every socialist will have to explain away more failures within his own ranks. At least we can learn from this Stalin-Trotsky fight that the principle of dictatorship can corrupt even the best-intentioned people.

I have seen letters of yours to Corbett and LeMesurier [sic], and am glad to know you are having an interesting time. I think you are right to take the extra year necessary for your degree, if you can manage it. It is a small time in relation to your future academic career, for which the degree and the work in Paris will be invaluable.

Nothing of special note is happening here. The job of surveying and reorganizing the work of the university is going steadily under Morgan, who in this respect is first rate. LeMesurier [sic] will make a good Dean if he keeps well; he has lots of ideas. We are pursuing the idea of a school of government.

In the country at large, the development is slow. the CCF members are putting up a good fight in Ottawa. They are as usual the only opposition. The new defence estimates give them an opportunity, but dear old J.S.W. is no rabble-rouser.

The recent Privy Council decisions are disastrous. They have split the country into provincial sovereignties even in the international field. The Quebec secessionists have had half their demands handed to them. This, and Spain, and Stalin, make blind faith necessary.

My best to Jeanne,

Frank Scott.

\title{
Explanation
}

\section{Paragraph $\mathfrak{l}$.}

Humphrey's wife was Jeanne Godreau (1903-1980), while Scott was married to artist Marian Dale (19061993). Scott had visited the Soviet Union in 1935 and, while disturbed by the repressive nature of dictatorship, believed somewhat wishfully that the situation was improving. ${ }^{2}$ Humphrey sent him a copy of André Gide's 1936 book, Retour de l'U.R.S.S. Gide had supported communism financially and ideologically since the beginning of the Great Depression, and was invited as an honoured guest to Maxim Gorki's funeral. Returning, he wrote a bitter critique of Stalin's policies and practices in which he renounced communism. Up to that point in time western socialists had held up the Soviet Union as a model of progress, although 
this position became more and more difficult to sustain as awareness of Stalin's excesses grew. Trotsky, who had been relatively silent since his exile in 1928, suddenly became more active at this juncture, establishing the Fourth International as a rival to the Moscow-based Komintern and becoming more vociferous in his criticisms of Stalin.

Paragraph 2.

Humphrey discovered in France that if he stayed at the university for a few months more and wrote a short dissertation, he could be awarded a doctorate. He wrote to Corbett and Le Mesurier, who became Dean in 1936, inquiring as to whether they would extend his leave to allow him to pursue the doctorate. Scott was evidently enthusiastic about the notion of graduate degrees for teaching academics, but his colleagues were less sanguine. On January 8, 1937 Le Mesurier wrote to Humphrey that, while he could extend the leave, there would be no financial assistance from McGill (Humphrey had suggested he be allowed to make up the missed work later). In terms of the value of the doctorate he added the following observation:

I realise of course the value of the degree to you in the event of your applying for a position in another university. We ourselves attach very little importance to it. This may be sour grapes but there it is.

When this drew a sharp response from Humphrey, he clarified matters on April 2 by saying:

When I said in one of my previous letters that we did not attach much importance to a doctor's degree I was simply referring to the tag and not the work which you are now doing.

\section{Paragraph 3.}

It may at first seem surprising that Scott, the radical young professor, would approve of the work done by Principal A.E. Morgan (1886-1972), the representative of the administration, but there were good reasons for the approval. McGill was in financial trouble during the Depression and survived in part through the sale of assets and the generosity of the Board of Governors, who voluntarily taxed themselves. Given this generosity Board members felt that members of faculty should present the capitalist view of society as vigorously as the socialist side seemed to be presented. In particular they wanted Morgan, who had been hired in June 1935, to do something about the outspoken Frank Scott. However, when the Chancellor Sir Edward Beatty (1877-1943) alerted Morgan to the socialist content of one of Scott's publications, the Principal responded:

I am glad you write to me, although I have no solution to offer for a problem which I hope will always be with us. I hope, because as I see it the only condition of its solution is the establishment of a totalitarian state, which God forbid!

In 1936, after McGill had undergone several years of retrenchment, Morgan had established a joint Staff/Board of Governors committee called the Consultative Committee on University Development. The ccmmittee's mandate was to examine the entire university in terms of current needs and estimate the cost of meeting these needs. Morgan was frequently at loggerheads with the Board of Governors on a variety of issues. He tendered his resignation as Principal on April 17, 1937 after less than two years in office. ${ }^{3}$ Le Mesurier served as Dean until 1946, although nothing appears to have come of his ideas for a school of government.

\section{Paragraph 4.}

The Cooperative Commonwealth Federation (CCF) was the original name for the New Democratic Party. James Shaver Woodsworth (1874-1942) became its first leader in 1932. The party elected several Members of Parliament in the 1935 federal general election, although the official opposition was the Conservative Party. Woodsworth was a respected Methodist minister and pacifist but not, apparently, a great orator. 
The 1937 budget predicted a deficit of $\$ 35,000,000$ while recommending that more than that amount be spent on armaments. This caused the socialist rallying cry of "Disarmament with a surplus".

\title{
Paragraph 5.
}

In 1935 Conservative Prime Minister Richard Bennett's government enacted "New Deal" legislation aimed at easing the effects of the Depression. This legislation included the Employment and Social Insurance Act, the Natural Products Marketing Act and the Minimum Wage Act. The nine provinces protested that these Acts were an infringement on provincial jurisdiction as defined by the British North America Act. In January 1937 the Judicial Committee of the Privy Council in London found in the provinces' favour, ruling almost all the legislation ultra vires.

\section{Notes}

1. The letter is currently in the possession of A.J. Hobbins, Humphrey's literary executor, but will eventually be donated to the McGill University Archives.

2. See F.R. Scott "Impressions of a visit to the USSR" Canadian Forum vol. 15 (December, 1935) pp. 382385. In this Scott stated "...the present dictatorship..involves tactics that positively hinder the attainment of socialism. Despite these qualifications I came away believing that the objectives of the revolution will eventually be achieved."

3. For a fuller description of the question of Scott, Morgan and the Board of Governors, see Stanley B. Frost, McGill University for the Advancement of Learning, Vol. 2 (Montreal: McGill-Queen's University Press, 1984) pp. 193-197.

\section{McGill Law Library Moves into Cyberspace(s)}

\author{
By Kate Williams \\ Director, University Relations Office
}

\begin{abstract}
"To leave no stone unturned" is the felecitous phrase from Euripedes engraved on the stone exterior of the new McGill law library, which was inaugurated on September 17, 1998 in the presence of Quebec's LieutenantGovernor Lise Thibault and hundreds of guests. "Given the years of effort to raise funds for the building, it is an apt reminder of what the University must do to sustain its margin of excellence and international reputation," says McGill Principal Bernard Shapiro. Hampered for decades by totally inadequate space while the student body increased by $50 \%$ and legal scholarship exploded, the old law library was considered one of the worst in Canada. Now, thanks to more than 300 donors, the new library welcomes users into a startingly different environment, one designed to bridge the past and the future in radical, sometimes light-hearted, sometimes sobering ways. The architect is Dan Hanganu, considered one of Quebec's hottest architects.
\end{abstract}

Named for major benefactor and graduate Nahum Gelber (B.A. '54, BCL ' 57 ), the $\$ 11.5$ million structure was made possible by large and small contributions from individual graduates, law firms, foundations and friends of the Faculty. "We're thrilled that so many people supported us," says Dean Stephen Toope. 